\title{
Correction: Ascorbate-induced oxidative stress mediates TRP channel activation and cytotoxicity in human etoposide-sensitive and -resistant retinoblastoma cells
}

\author{
Jakub Oronowicz - Jacqueline Reinhard - Peter Sol Reinach (1) - Szymon Ludwiczak • Huan Luo • \\ Marah Hussain Omar Ba Salem • Miriam Monika Kraemer • Heike Biebermann • Vinodh Kakkassery • \\ Stefan Mergler (iD
}

Published online: 18 June 2021

(c) The Author(s) 2021. This article is published with open access

Correction to: Laboratory Investigation

https://doi.org/10.1038/s41374-020-00485-2

Three different clarifications are warranted to better understand our findings and conclusions.

(1) On page 9 in the PDF version, subtitle "Medium acidification has less influence on $\mathrm{Ca}^{2+}$ regulation" should instead read:

Role of Asc-induced acidification in increasing $\mathrm{Ca}^{2+}$ influx

Section summary clarification: The role was reevaluated of Asc-induced medium acidification in contributing to increases in $\mathrm{Ca}^{2+}$ influx. We wish to clarify that the responses to Asc were much larger than those induced by medium acidification. Therefore, lowering the $\mathrm{pH}$ does not account for how Asc increases intracellular $\mathrm{Ca}^{2+}$ influx.

(2) Subtitle for Fig. 10 should be corrected as:

Acidifying-induced $\mathrm{Ca}^{2+}$ transients in etoposide-resistant and -sensitive WERI-Rb1 cells

(3) The following alteration is more precise regarding the role of TRPV1 channel activation during medium acidification. (page 11 - paragraph 2 and page 14 - paragraph 3; PDF version):
Section summary clarification: TRPV1 activation does not contribute to the small increases in $\mathrm{Ca}^{2+}$ influx resulting from medium acidification. This channel is not involved since the decline in $\mathrm{pH}$ occurred over a range known not to alter its activity. We suggest that mechanisms other than acidification are the main contributors underlying Asc-induced $\mathrm{Ca}^{2+}$ transients. Moreover, WERI-Rb1 cells possibly possess other $\mathrm{pH}$ sensitive pathways since lowering the $\mathrm{pH}$ induced significant increases in $\mathrm{Ca}^{2+}$ influx.

These corrections do not affect the results and conclusions of the article.

All authors agree with the corrections.

Open Access This article is licensed under a Creative Commons Attribution 4.0 International License, which permits use, sharing, adaptation, distribution and reproduction in any medium or format, as long as you give appropriate credit to the original author(s) and the source, provide a link to the Creative Commons license, and indicate if changes were made. The images or other third party material in this article are included in the article's Creative Commons license, unless indicated otherwise in a credit line to the material. If material is not included in the article's Creative Commons license and your intended use is not permitted by statutory regulation or exceeds the permitted use, you will need to obtain permission directly from the copyright holder. To view a copy of this license, visit http://creativecommons. org/licenses/by/4.0/. 